\title{
Obstacles to Nigeria Political Development - A Critical Evaluation
}

\author{
Emma E.O. Chukwuemeka, Ph.D (Corresponding Author) \\ Department of Public Administration, \\ Nnamdi Azikiwe University, Awka, Nigeria \\ Email: ee.chukwuemeka@unizik.edu.ng,hrvkonsult@yahoo.com, Tel: 08060967169
}

\author{
Prof. J.C. Okoye, Ph.D \\ Department of Public Administration, \\ Nnamdi Azikiwe University, Awka, Nigeria
}

Prof. E.A. Egboh

Department of Political Science, also, Dean, Faculty of Social Sciences, Nnamdi Azikiwe University, Awka, Nigeria

Ngozi Ewuim

Department of Public Administration, Nnamdi Azikiwe University, Awka Nigeria

Received: April 11, 2012 Accepted: May 18, 2012 DOI: 10.5296/jpag.v2i2.1987

\begin{abstract}
Nigeria is one of the fast developing nations of the third world, but has many obstacles to her political development. The military ruled Nigeria between 1966 to 1979 and 1984 to 1999 . Military dominance in Nigeria

Politics has in no small measure impacted negatively on the political development of Nigeria. Therefore political development of Nigeria has been going at a snail speed not only due to frequent military incursion in government but also due to many other impediments which include ethnicity, incumbency politics, tenure elongation, godfatherism and poor political
\end{abstract}


orientation. The paper which is theoretical and persuasive examined all these factors critically and recommended among other things that National Assembly should pass a law to make elective office a single tenure. The economy of Nigeria should be organized to make it more productive and also to devise a vision of society within which each person can reasonably perceive that equity and social justice are firmly on the national agenda. To eradicate ethnic politics in Nigeria efforts should be made towards equitable distribution of social, political and economic gains of the polity. Finally efforts should be made to enforce the section of the constitution that dwelt on the formation of political parties that are devoid of ethnicity.

Keywords: Obstacles, Military, godfatherism, Incumbency

\section{Introduction}

Nigeria gained her flag independence by October 1, 1960, and by 1963, she became a Republic. The first indigenous elections in 1964/65 were marred by bloody incidences and these torpedoed the civil rule by giving military the opportunity to execute a coup by January 15, 1966 (Anyanwu, 2003). This ended the Nigerian $1^{\text {st }}$ Republic. The January 15, 1966 coup brought about counter coups, which eventually culminated in the 1967-1970 Nigerian civil war fought between Nigeria and Biafra. Biafra was primarily people of Igbo extractions. They fought to resist untoward reactions of their brothers of Northern extractions as depicted by the brutal murder of Igbos in the North.

The military continued in power up till May, 1999 because Nigeria was unable to nurture an enduring democracy. Nigeria's return to democracy on May 29, 1999 after a tortuous transition programme was greeted with monumental expectations on the part of the citizenry and attracted the attention of the international community and a legion of scholars.

It should not pose any difficulty to a discerning mind to deduce that Nigeria's fledging democracy is beset by a plethora of bottlenecks at the heart of which is the negative use of power and poor distribution of democracy dividends. The negative use of power of incumbency is yet another bottleneck. Literally, the incumbency factor refers to the unrestricted access that the current holder of a political office has to state machineries and resources which he can deploy to his advantage and against his opponents. This has reared its ugly head in all the elections conducted in the country since the return to democracy, 2003, 2007 and 2011.

Procedures for transfer of power are not also strong in Nigeria; the procedures are not orderly as to be compared with what obtains in western capitalist nations and even most new states like Philippines, India etc. Furthermore, the messiah ship euphoria and sycophancy that follow any new regime in power leaves nothing to be desired. The meddlesome manner about Nigerian democracy is overtly awful and unhealthy to sustain development. If the practice of democracy in Nigeria fails to agree with the principles of ideal democracy conceived and nurtured by Aristotle, then Aristotle must have labored in vain. The Greek Philosopher, Aristotle identified and conceived three principal forms of government which are desirable and attainable. The first one is "kingship" which he defines as government by a man with preeminent virtue; a god among men. The second one is "aristocracy" which he calls 
government formed by the best men in society. This is a system of government in which citizens at large govern for the common good. It involves the attempt to unite the freedom of the poor with the wealth of the rich. When the poor are in the minority and seize power it becomes a democracy (Appadorai, 1981).

Aristotle believes that these three forms of government can be perverted. When kingship is perverted, it becomes self serving and tyranny is the end product. When aristocracy becomes self-serving it is transformed into mob rule. Aristotle was realistic enough to believe that desirable as they may be, kingship and aristocracy are unviable (Uzochukwu, 1997; Ugwu and Chukwuemeka, 1997)

\section{Objectives of the paper}

The broad objective of this paper is to evaluate the political development of Nigeria from 1960 to date and identify possible obstacles impeding on smooth development of the Country politically. Specifically, the paper is set out to:

(a) Examine the extent ethnicity impact on Nigeria political development

(b) Also to examine how incumbency and military incursion in Nigeria politics have affected the political development of Nigeria with a view to suggesting the way forward.

\section{Democracy - Etymological and theoretical discourse}

The Dictionary of politics defines 'democracy' as a derivation from the Greek words 'people and power' originally referring to the right of the citizens of the Greek City -states to participate directly in the act of governance. There is alliteration in form of a definition of democracy "the government of the people, for the people and by the people". However, the term 'democracy' has been perceived and defined in various other ways by different political scientists. Some of such definitions could be found in Umez (2002) who used the word 'democracy' to mean, a statement about 'sovereignty' and nothing else. He contends that 'sovereignty' in the adult population is established and it is nurtured when a representative government permits and maintains certain basic principles. He identifies these principles as (a) universal political participation (b) political equality (c) majority rule (with substantive recognition of minority right(s), (d) rule of law (e) government responsiveness to public opinion and (f) the basic freedom of speech, press, assembly, religion and organization (Uchechukwu, 2005).

Essentially, this definition, full blown, has not ignored the important features of an ideal democracy.

Harris (1979), Okibe (2000) and Ugo (2005) define democracy as the control by the vast majority of the inhabitants of a country or popular controls' the central theme in this definition is that 'democracy' is rule of the people. In which every way we look at these definitions, one thing is clear, that democracy is the rule by the majority through representation. It involves popular participation and popular opinion. Since democracy in Nigeria falls short of the underling standard, democracy has not started well in Nigeria. 'Nigerian democracy' is synonymous with 'Marxian democracy'. Disciples of Karl Marx see democracy as the governance by the minority, the privileged minority who ascend the reigns 
of governance and use power for the improvement of the living conditions of their supporters and sycophants. They are therefore always striving to create avenues for the acquisition and consolidation of more power at the expense of the majority. Democracy to them does not serve the interest of the masses. The oppressors merely seize state power to loot government treasury (Ndibe, 2009). To an extent democracy in praetorian polity like Nigeria is not far from this assumption.

Democracy in Nigeria no doubt is also at variant with Aristotle's vision.

Between $6^{\text {th }}$ and $4^{\text {th }}$ century B.C. Aristotle inculcated in the people of Athens, the need for democracy as the best form of government which will suit the needs of their people. According to him kingship and aristocracy do not encourage mass participation in governance (Fords, 2000). The Masses ought to participate in governance. Ruler-ship should be open to all and sundry, even though everyman would not rule at the same time, hence representative democracy. Representative democracy or government contends Oji (1998), is accepted as a way of ensuring the actual participation of the generality of the people in politics, by instituting a government in proxy. The people were then governed under a framework which ensured the principle of 'one man one vote' in elections and which guaranteed that the custodians of the people's mandate ruled in accordance with the general will (Adesina, 2006).

We reiterate the fact that what is practiced in Nigeria today is not ideal democracy. It is suicidal to call it one. Superfluous as the allegations may be, the truism was that rigging, thuggery and flagrant falsification of figures were rampantly witnessed in the various elections conducted in Nigeria from 1963 till date. The only point of contention was which party was not engaged in rigging? The salient point of concern and consequent complaints was the issue of degree of rigging. Suffice to say that some parties were only interested in rigging a particular election.

The type of democracy practiced in Nigeria falls short of the following principles as enunciated by Jones (2006)

(a) Equality - equalitarian status for all persons in the polity

(b) Alternative choices - the masses should be able to decipher the type of political ideology, party or interest which suits their desires.

(C) Regular consultations - people should be consulted over debatable issues, to air their views and discuss with the elected representatives when necessary. Government should avoid taking decisions arbitrarily.

(d) Regular elections - ideal democracy should be devoid of absolutism, despotism and 'sit-tight' leadership/tenure elongation. Regular election should be held to elect new candidates from the masses. Even if the incumbents should continue on the demand of the majority, elections should be conducted to test their candidacy.

(e) Majority rule - ideal democracy should adopt populist programmes which should be in the interest of the masses.

(f) Enlightened electorates - citizenry ought to be educated and awareness created in the 
workings of government. Political socialization should also be inculcated in the electorates to avoid anti-democratic electoral practices

In the present political dispensation in Nigeria, one wonders whether what is practiced in the name of democracy is agreeable to these principles. If the answer is in the affirmative, good but if 'No' is the answer one could simply brand the present democracy in Nigeria 'civilian rule'. However, there is hope that from civilian rule Nigeria may advance to democratic rule. It is a process. From colonialism to military rule, from military rule to civilian rule, from civilian rule to democratic rule. The stage of freedom from self serving, ethnicity, looting of public treasury and oppression.

A passable understanding of the term democracy contend Oji (1998), Howard (1995), Jones (2006) stands out as a positive movement which elicits a feeling of acceptance from the generality of the people. It is the catalyst to political, economic, technological and social development and change which emphasizes majoritarian rule. There is no gainsaying that democracy is government by representation of a majority of the people for their mutual benefit.

\section{Incumbency influence/advantage thesis and distribution of democracy dividend}

This refers to the interplay of forces through which an incumbent leader or party attempts to influence and manipulate the constitutional and institutional framework that guides the electoral process thereby creating an unequal playing for the contestants in the electoral competition (Nwanegbo, and Alumona, cited in Alfa (2011).

As stated earlier, the incumbency factor implies the unrestricted access that the current holder of a political office has to state machineries and resources which he can deploy to his advantage and against his opponents. (Olusola-Obasa, 2011).

Explaining the source of this incumbency advantage has been one of the most active topics in the study of American politics over the past quarter century. The dominant explanation is that the incumbency advantage is caused by the ability of members of congress to provide constituency service (e.g. Fiorina 1977). Or Cain, Ferejohn, and Fiorina (1987). Members of congress, the argument goes, provide local public goods to their constituents and thereby shore up support for themselves. Indeed, Levitt and Snyder cited in Alfa (1997) and Fiorina and Fiorina and Rivers (1989) find evidence that incumbents who provide more pork-barrel spending or have greater district presences are more successful in their re-election contests. Recently, Cox and Katz (2002) suggested that redistricting also plays an important role in explaining the electoral success of incumbents. However, later set of empirical findings show that other variables exist (Ansolabehere and Snyder, 2002).

In the case of Nigeria, elected representatives are, more often than not, self-centered and do not have to embark on service delivery to win re-election. This is a function of the fact that, being in government, they have the advantage of using state resources and this scenario is helped by pervasive poverty among the citizenry who rarely take the consequence of their electoral actions into cognisance (Bola, 2011).

Ugwu (2002) in Nwanegbo, and Alunona, (2011) rightly observed, the manipulation of the 
electoral process by incumbents in power can take place at the three level of electoral governance. These are at the levels of rule making, rule application, rule adjudication. The manipulation can manifest in a wide range of activities that sustains the electoral process such as: enactment of electoral law and the constitution, appointment of electoral management body, appointment of election tribunals and the conduct of the elections. The manipulation of the electoral process can also come in various forms, such as: appointment of corrupt and or compromised electoral officers, manipulation of the electoral law and the constitution, manipulation of the election tribunal to protect stolen mandates, use of state resources to bankroll election campaigns, use of state, security forces and apparatuses to intimidate opposition parties, denial of access to state owned media houses etc.

It is imperative to recall that during Obasanjo's second tenure in office-2003 to 2007, he strove to retain power by lobbying the National Assembly to amend the constitution to smuggle in the third term clause but the inability to get $2 / 3$ majority of the senators circumscribed the ambition. The opposition of the vice president, Alhaji Atiku Abubakar to the $3^{\text {rd }}$ term plot pitched him on a collision course with the president who ensured that the principle of "deregistration" was used to frustrate him out of the ruling people's Democratic Party.

It is also not news to Nigerians and keen followers of Nigeria's political trends that the role of the former chairman of INEC professor Maurice Iwu in the infamous 2007 elections is a reflection of the abysmal influence of incumbency factor on the electoral process because president Obasanjo did not mince words to tag the election a do or die affair (Egwemi, 2008).

Incumbents in Nigeria are also notorious for unleashing terror on real, perceived or imaginary enemies. This brutalization of opposition parties' supporters during electors are well documented (Chukwu, 2007).

Against the backdrop of abysmal wielding of incumbency influence on government and party operations in Nigeria, Anyaoku (2010) bemoaned that "to ascribe undue influence, especially self-serving influence to the parliamentary group of the party in the selection of candidates would seriously undermine the democratic process"

\section{Democratic consolidation}

Democracy is consolidated when, under given political and economic conditions, a particular system of institutions become the only game in town, when no one can imagine acting outside the democratic institutions, when all losers (of political contest) want to try again within the same institution under which they have just lost"..

Also reinforcing the above perception, O Donnell in (Alfa, 2011) argued that a democracy is consolidated when power is alternated between rival parties, support for system is continued during time of economic hardship, rebels are defeated and punished, the regime remain stable in the face of restructuring of the party system, and there exists no significant anti-system.

Judging from these expressed views; Nigeria's democracy has a long way to go as far as the consolidation journey is concerned. This is due to the obvious fact that if measured against the outlined paradigms, the Nigeria's democracy is a gross deviation; those in government 
emasculate the opposition and often times, those who loose election resort to violence (Adeyomo, 2011); Ige, et al cited in Alfa (2011); (EU EOM, Report 2011).

In outright contradistinction with the above tenets, the Nigeria's experience since 1999 has been unremarkable. The political class, cutting across all the political parties, behaves as if they are unaware of the values of democracy.

\section{Manifestations of incumbency influence in Nigeria.}

The abuse of the influence of incumbency is a major cankerworm eating the fabric of the Nigerian fledgling democracy. It has brought about the following developments in the polity.

- Elite fractionalization: The indiscriminate use of incumbency polarizes the elites as the chief executives of states often super-impose their whims and caprices on party members and supporters. For instance the recent directive by the Peoples Democratic Party (PDP) for fresh primaries is threatening the ranks of the party's contestants is five states. (Ezeani, 2011).

- Promotion of mediocrity and sycophancy: The lack of institutionalization of parties in Nigeria (Bola, 2011) provides a fertile ground for sycophants and political praise-singers to have field days as they massage the ego of unprincipled incumbents even in the face of unpopular decisions and policies. In Kogi State, such sycophants prostitute between political aspirants and relish schism among them to enhance their enrichment. They were claims that the outgoing governor, Ibrahim Idris had the intention of making his son-law his successor by undermining the wish of the majority of PDP members in the state.

- Misuse of fund: Abuse of incumbency also has a correlation with misuse of fund by the incumbents. They share money to lobby people to support their self-serving interests and neglect the development needs of the masses.

- Political apathy: When people get disenchanted by the infamous acts of the incumbent(s), the corollary of it is that people become alienated from the polity given that their views and interests do not count. As such, there would be a decline in participation in political processes.

- Defection: When incumbents turn octopuses and dominate all affairs of the party and/or government, some aggrieved party members' cross-carpet. No wonder then Tenuche (2011) identify defection as a consequence of absence of internal democracy in Nigerian political parties.

- Political violence: At times, some parties' supporters could become dissent as a result of the disadvantaged position they found themselves due to the gross intrigues that characterise party politics in Nigeria. Oftentimes the disadvantaged and favored group clash. The series of bomb blasts in the country before and in the wake of the 2011 elections might not be unconnected with this reality (Alli et al 2011) (Adekanbi \& Akintunde, 2011). 


\section{Incumbency and Nigerian Politics}

Recent experience in Nigeria indicate that performance politics seem to be taking precedent over the hitherto overarching influence of incumbency factor in determining political events and especially electoral victories (Ezeani 2011, Alfa, 2011).

Effective opposition, credible election, excessive reliance on godfatherism, autocratic style of leadership and increased political consciousness on the part of the citizenry are some of the underlying factors sounding a death knell to the significant role of incumbency in the political equation of Nigeria. (Bola, 2011).

In Oyo and Ogun states, it backfired. Although Ogun Governor Adebayo Alao-Akala and his men succeeded in edging out senator Teslim Folarin of the primaries, the centre could still not hold as things fell apart.

Former Governor Rashidi Ladoja, who suffered similar fate, left the party with his followers. Adesina,( 2009).

In his critique of 2011 polls and role of incumbency, Chukwu, (2011) notes "the political wind that blew across the entire South West was unanticipated by the PDP which failed to manage their success in the zone. The party was ridden with crises to the extent that the falcon could not hear the falconer, hence things fell apart and the centre could not hold".

The PDP which was in control of five states in the zone (Oyo, Ogun, Ekiti, Osun, and Ondo) in 2007 after the political earthquake that swept the area from its traditional holder, Alliance for Democracy (AD), failed to take the same state to the end of the four-year term.

As Fadre cited in Alfa (2011) added, the reasons are that the General Election that produced the political office holders particularly the governors in the country were massively rigged. With the rulings by the judiciary, Ondo, Ekiti and Osun were reclaimed by the Labour Party (LP) and ACN respectively. As if these were not enough, the remaining states of Ogun and Oyo fell like a pack of cards into the hands of ACN. As Bola (2011) noted, "...it was the PDP that boxed itself into a corner due to their selfish interest".

Corroborating the above is Adaramodu in Alfa (2011) who asserts that the victory of ACN over PDP is liberation from underdevelopment and poverty. This explicates that the people of the region did not witness positive transformation under PDP governors. Linking the past victory of PDP to abuse of incumbency, and a corrupt electoral body, Adaramodu bluntly asserts "it was possible for the PDP to overrun the south -west in the 2007 elections because of the unscrupulous character of their then self acclaimed leader, who succeeded in imposing governors on the southwest states through the machinery of the federal government, aided by a rapaciously devious electoral umpire.

Another state where incumbency failed to be valid was Nassarawa State. Witch-hunting of perceived political enemies, egoistic posture, inaccessibility, poor sense of judgement, etc., all combined to cause the defeat of Aliyu Akwe Doma in the 2011 gubernatorial election by the opposition CPC candidate Umar Tanko Alkmakura. He was alleged to have been too slow in his developmental stride and paid deaf ears to the plight of workers perhaps banking on the hope to triumph simply through incumbency advantage. However, it did not work out for him. 
The peoples' political consciousness has been enhanced and they voted him out (National Accord, 2011).

As documented by Sahara Reporters, another former governor who relied on the power of incumbency to win election but got his hopes dashed was Ikedi Ohakim of Imo State. The Imo electorates, despite, postponement and cancellation of some wards voted out Ohakim due to what Sahara Reporters call "Misrule and Corruption". (Sahara Reporters, 2011).

The political feud between the former governor of Zamfara State, senator Sani Yerima and the immediate past governor, Mamuda Shinkafi rendered the incumbency influence unworkable in the state. The political squabble led senator Sani Yerima to throw his weight behind Alhaji Abdulaziz Abubakar Yari who won the election. This indicate the earlier position that elite factionalisation negate the capacity of incumbents to win re-election. .

It is instructive to note that it was not only state governors that bear the brunt of failure of incumbency factor in facilitating their successes at the polls in the 2011 elections. At the end of the April 9 and 26 National Assembly elections, a total of 73 senators lost the battle to retain their seats in the upper legislative chamber: (Chukwuemeka,, 2011).

\section{Failure of Political Mobilization organs in inculcating ideal democratic habits in the people}

Three political mobilization organs are selected for discussion in this section of the paper. They are the National Orientation Agency (formerly MAMSER) established by the despotic Babangida military junta, the press and the Ministry of Women Affairs (former Commission for Women). Yet another outfit of the Babangida's totalitarian and oligarchic regime.

The National Orientation Agency's mandate is to promote the cultivation of positive mental attitudes towards the National quest for economic recovery and development and inculcate in the people a new social and political order devoid of ethnicity (Ugwueze, 2005). The Agency's role in political mobilization contends Oji (1997) is a process by which programmes are designed and undertaken to create awareness in the people for understanding and support of governmental policies and actions, to inculcate in the masses positive values, habits, orientation without coercion, to create awareness of the resources at their disposal as well as their ability to transform their socio-economic, political and cultural lives.

ONational Orientation Agency organized workshops, seminars and rallies from time to time, all aimed at mobilizing the citizenry on positive political habits. The big question is this - "is the organization actually doing its work? If yes, how successful were the campaigns and how have they affected the political habits of the masses? Why it is that ethnic consciousness is still very high in Nigeria politics?

The inevitable collapse of the second republic brought about by gross mismanagement and lawlessness appears to have no historical significance in view of what is happening now. The senate, the house of representative keep changing headship. Most state houses of assembly have changed headship for more than four times within two years (Uzoamaka, 2007). In the house of representative the last change was predicated by corrupt enrichment by a woman lawmaker, Mrs Patricia Ete. A cursory look at the National Orientation Agency indicates that 
either that it has not done its duties well or that it has lost its focus. Little wonder, writers have criticized the organization on grounds of ideological crisis. Its birth was as a result of the political Bureau's recommendation that it be the political orientation arm of the socialist ideology it opposed (Ogbenna, 1998). Babangida rejected socialism but went ahead to create NOA. Okolo (1998), Chukwuemeka, Aba and Eze (1998) and Ezeani (1986) contend that the mobilization campaigns began without a clearly defined and thoroughly articulated set of objectives but only a loud media event. The programme could have been successful in a socialist economy than under crude capitalist society like Nigeria (Edeani, 1986). The objectives of the Agency are too burdensome and far - flung. Again it has failed to re-orient the nation's leadership towards change in attitude and practice for example, the "grab-it-all syndrome", "settlement culture", thuggery, election maneuvering, bribery and corruption and all other forms of leadership vices and anti- democratic practices still exist among the ruling class. Lately the anti-graft agencies were established by Olusegun Obasanjo (Independent Corrupt Practices Commission and Economic and Financial Crime Commission), yet corruption has even increased among political officer holders.

The press which supposed to be a powerful vehicle for political mobilization has turned to be mouth piece of the despotic leaders. The press is rather used for political sycophancy. As an agent of the political mobilization, the press is expected to explain national issues to the citizenry, present the feelings of the citizenry to such issues, and provide unbiased assessment of governmental sections and act as society's watch dog on national policies (Ogbenna, 1998). It is the duty of the press to inform the citizenry or sound an alarm when stated objectives or ideal political norms are deviated from.

The Commission for Women which was in association with the Better Life for Rural Women also lost its objectivity. The Organization was primarily charged with the responsibility of mobilizing the Nigerian women politically and the development of their individual and as well as collective capabilities. Instead of the programme filtering into the grassroots to create awareness among the rural illiterate women, it was rather hijacked by wives of the governing elites who scarcely interacted with the rural poor and illiterate women. This ugly trend has left the rural populace especially women apolitical.

This discourse could not be complete without making reference to the role of the Electoral Commission. It was first called Federal Electoral Commission, later it was changed to National Electoral Commission by Babangida. General Abacha rechristened it Independent Electoral Commission. The truth is that there is nothing "independent "about the Commission.

The Electoral Commission which is in charge of conducting credible elections always play the chicken hearted role by playing into the hands of politicians who wield so much influence at the grassroots. To secure an Electoral Commission job, one needed nothing apart from being conversant with the area where one intended to conduct the elections. The implications of this worse provisions in appointment or recruiting electoral officers, was that mainly school teachers were recruited and put in the ultimate position of king makers especially so when they had the powers of producing election results. By nature teachers are the most familiar workers to the villagers. One could say that after all the electoral officers are no 
longer allowed to work in their areas. That is not true. The truth is that the Electoral Commission, electoral officers and the so called new breed politicians are corrupt to their ears (Chukwu, 2007).

\section{The Influence of ethnicity on Nigerian democratization}

Ake (1991), Bola (1998) and Dike (2005) argue that nothing is inherently conflictual about ethnic differences. They lead to strife only when they are politicized, and it is elites who politicize ethnicity in their quest for power and political support. The foregoing argument is not out of place. It is the political elites that manipulate ethnicity for their selfish desires. In the words of Momo (1997) "ethnicity serves the interest of the ruling class that replaced the departed colonialists, even though it is a colonial creation".

The link between ethnicity and politics appears both obvious and automatic in relatively new states with the effect of ethnicity so prevalent and the consequences of their inter-ethnic conflicts so evident and transparent, it is little wonder that it has come to be seen Nigeria as a serious obstacle to liberal and ideal democracy.

Ethnicity is undoubtedly a very powerful weapon for the production of political leaders in Nigeria argues Nweke (1996). As tension and ethnic consciousness becomes very high, people with political motives gradually emerge and insist on fanning members of ethnic identification, these politicians sooner or later gang along ethnic lines to gain cheap popularity. Before the Nigerian civil war, most politicians and political parties were formed on ethnic basis, e.g. the defunct National Council of Nigeria and the Cameroon (NCNC) with its taproot in the then Eastern Region led by Chief Dr. Nandi Azikiwe, Action Group with its stronghold in the then Western Region led by late Chief Obafemi Awolowo and Nigerian People's Congress (NPC) with its stronghold in the then Northern Region led by late Alhaji Ahmadu Bello. These leaders used intensive ethnic propaganda coupled with intimidation to win fierce loyalty and support from followers. They were even regarded as "small gods" by many ethnic subjects. Different myths surrounded and protected these leaders.

Egboh et al (2010) also hypothesized that the higher the status positions of a person, the greater the following: the tendency for that person to internalize responsibility for an approved state of affairs, the tendency to attribute good intensions with respect to his positive actions relevant to the status dimension as justified. Ethnic attribution in Nigeria has direct relationship with status of the person concerned. To an average Yoruba man, whatever the late Awolowo did or said was good, constructive and well intentioned, "he was the father of the nation". The same is true of other ethnic groups and their leaders. Each leader is seen by his people as the founder of peace and "one Nigeria".

Ethnic attribution is often used by most Nigerian politicians for rationalizing failure and frustrating fate and for invasion of political opponents. As most politicians become increasingly successful, ethnic attribution decreases as source of anchor or explanation of fate. On the other hand, as these politicians are displaced from the centre or in high government positions, the higher the attribution of responsibility to ethnicity. These politicians often rally their subjects and explain failure in terms of ethnic victimization. These people are often used as instruments for retaliation, hostility, chaos, upheaval and protests. This attribution pattern 
is dangerous for the country Nigeria as a nation. Ministers, state commissioners, ambassadors, directors of public companies, heads of parastatals, governors, and political contractors rationalize their failures in this way.

In most cases religion is attached to ethnicity as a political tool. During the presidential election in April, 2011, the Muslim North rallied round Retired General Muhammad Buhari as a consensus candidate while the incumbent President, Goodluck Jonathan garnered support from the Christian faithful who constitute the major population Ibo and Yoruba ethnic groups. Before the result of the said election was announced which was to be in favour of Goodluck Jonathan, the Northern youths in Kano, Kaduna, Maiduguri and Bauchi started rioting and killing innocent Christians from the western part of the Country.

Ethnicity has also played very vital role in the Nigerian first and second republics. It also made serious impact in the aborted third republic and presently, it is rearing its ugly head through elite manipulation (Ugwu and Chukwuemeka, 2000). Also during the second republics, the political parties were founded on ethnic interests and identification. The structure, leadership and membership of the parties equally manifested ethnic affiliation. In the present dispensation the three major reigning political parties have ethnic linings. The parties are Alliance for Democracy (AD), All Nigeria Peoples' Party (ANPP), the ruling party Peoples' Democratic Party (PDP). The AD which metamorphosed into Action Congress of Nigeria $(\mathrm{ACN})$ is predominantly the party of the western Nigeria. The ANPP for the Northern Nigeria while the PDP as the ruling party is dominated by the North and West.

The annulled June 121993 elections in Nigeria by Babangida were based on ethnicity. However when the election was annulled, ethnicity set in as southerners protested over the annulment which they saw as designed to scheme a southerner (M.K.O. Abiola) out from becoming the president of Nigeria.

\section{Conclusion and Recommendations}

The inability of Nigeria to nurture ideal democracy has impacted negatively on the political development of Nigeria.

From the foregoing, it is obvious that the critical role of incumbency influence in political processes in Nigeria is profoundly indubitable. The dynamics of power out play in the 2011 elections also reveal that the validity of the phenomenon of incumbency in deciding political issues is not everlasting. The outcome of the elections is indicative of the fact that the political consciousness of Nigerians is on the rise. Consequently performance politics remains the surest avenue that guarantees electoral successes in future elections, thus incumbency has limitations. This would deepen the entrenchment of democratic norms and ultimately accelerate the boat of democratic consolidation in Nigeria. We make bold to recommend as follows:

(a) The constitution of Nigeria made it difficult for an ethnic group to form a political party. It emphasized ethnic spread as a requirement for recognition of political party. But all these are paper work. Today political party formation is still based on ethnic factor.

It is the candid view of the paper that the pursuit of a genuine democratization requires: 
(b) The National Assembly should pass a law to make elective office a single tenure

(c) Organizing the economy to make it more productive and also to devise a vision of society within which each person can reasonably perceive that equity and social justice are firmly on the national agenda.

(d) For eradication of ethnic politics in Nigeria, efforts should be made towards equitable distribution of social, political and economic gains of the polity. The political parties should not have ethnic oriented background.

(e) Introduction of Muslim and Christian religions as compulsory subjects in all Nigerian primary and post primary schools.

(f) Development of National political education and making it part of school curriculum. A Commission should be set up at federal and state levels to run this programme. Experts in various fields with national consciousness should be appointed into the commission.

(g) A law should be promulgated to restrict retired military officers from becoming members of political parties. They should also not stand for election into political offices.

\section{References}

Adesina, S.O. (2009) "The myths surrounding ethnic politics in Nigeria" Journal of Politics, 2(4) $34-40$

Anyanwu, T.O. (2003) “Gunmen in politics “Journal of Social Policy (2) 2. 23-24, May

Ake, C (1992) The Feasibility of democracy in Africa, Olbacan CREDU,

Alfa, P.I. 'Political parties and democratic consolidation in Nigeria (2007-2011) Journal of Policy and Development Studies 5(2) 149-160

Bola, D A. (2011) "Social Policy: A bag on the path" Nigerian Management Review, 5(2) $13-18$

Chukwuemeka E.O. (2008) “A pathological review of military democracy in Nigeria” Journal of Policy and Development Studies May. 2(1) 5-7

Chukwu, D.O. (2007) "The myths of electoral law in Nigeria" African Development Review, August, 3(2) 5-6

Chukwuemeka, E.O., Abah N.C., Eze, F.O. (1998) Public Administration and Development: The Nigerian Experience, Enugu: Marydan Publishers

Dike, F.O. (2005) "The problem with democratization in new states" African Development Review, August, 3(2) 20

Dinkins G (2000) "Democracy and Governance - A Comparative View" British Journal of Political Science 9(5) 12-15

Ezeani, D.O. (2011) “The Nigerian Press and the urgent challenge of National Mobilization”, A symposium by the Association of Mass Comm. Students, ASUTECH, August, 27 p.3 


\section{Macrothink}

Journal of Public Administration and Governance ISSN 2161-7104 2012, Vol. 2, No. 2

Ezeani, E.O. (1998) "The poor and democratic experiments in Nigeria: A theoretical And experimental analysis", Nigerian Journal of Public Administration and Local Government 9(1) 51

Egboh, E.A., Okeke V.O.S, Anichie E.T (2010) Comparative Federalism: A SystematicInquiry, Nimo, Rex Charles and Patrick Publications

Flamigan, W.H. and Zingale, N.H, (1972) Political Behavior of the American Electorate $3^{\text {rd }}$ ed. Boston: Allen and Bacon Inc.

Ford, J.O. (2000) "Election in America" Journal of Policy and Administration 11(14) 35

Harris, P.B. (1979) Foundation of Political Science, London: Hutchison \& Co. Publishing Company.

Howard, Z (1995) "How democratic is America" in Robert E. Didanco and Allens SHammock (eds), Points of View: Reading in American Government and Politics, New York: McGraw Hill - Inc

Jones, U (2006) Political Science, New York: McGraw Hill Book Co.

Madiebo, A (1980) The Nigerian Revolution and the Biafran War, Enugu: Fourth Dimension Publishers.

Nweke, C.C. (1996) 'Ethnicity and Attribution patterns as foundation sources of Instability and insecurity in Nigeria' Great Issues in Nigerian Governmednt And Politics, Enugu: Marydan Publishers.

Ndibe, G.O.(2009) Politics and Government in Developing States, Lagos, Mangroove

Oji, E (2000) Politics in Nigeria, Lagos: Mangroove publishers

Okechukwu, R.O (1997) An Introduction to Political Science, Enugu: Marydan Publishers.

Okechukwu R.O. (1997) "Strategies to democratic mobilization in Nigeria, in Udeabah

S.I. and Okechukwu R.O. (eds) Transition in a Depressed Economy, Nigeria Case, Enugu: Auto Century, Publishers.

Ogbenna P.O.,(1998) "Women and Political participation, A study of women and Politics in Umuahia South LGA of Abia State", unpublished B.Sc Project In Political Science, ESUT

Okibe, H.B (2000) Political Evolution and Constitutional Development in Nigeria (1861-1999), Enugu: Marydan Publishers

Uzochukwu, R (1997) Elements of Politics in Nigeria, Lagos: Vinez Publishers.

Uchechukwu, H.W(2005) "Women political participation in Nigeria- a critical view"Journal of Policy and Development Studies, 1(2) 6

Ugwueze T(2005) Elements of Citizenship, Enugu: HRV Publishers

Uzoamaka ,C.O.(2007) "Democratization in Nigerian Local Government System" Journal of Education Research, 5(2) 13-20

Ugwu S.C. and Chukwuemeka E.O.(1997) “Transition programme,Ethnicity, Religion And 
women participation in politics" A paper presented in a conference organized By UNDP , Enugu..

Ugo, M.K (2009) Trends in Social Studies, Ibadan: Heinemann 